\title{
STRATEGI DAN RENCANA AKSI PENGEMBANGAN PELAYANAN SOSIAL PERKOTAAN (URBAN SOCIAL SERVICES) DALAM RANGKA MENINGKATKAN DAYA DUKUNG KAWASAN DI WILAYAH DKI JAKARTA.
}

\author{
JOKO CHRISTANTO
}

Fakultas Geografi UGM, Yogyakarta

Email: joko_yogya@yahoo.com

\begin{abstract}
Abstrak
Artikel ini ditulis berdasarkan penelitian yang dilakukan di wilayah Propinsi Daerah Khusus Ibukota Jakarta bertujuan untuk meningkatkan dan mengembangkan fasilitas pelayanan sosial perkotaan sesuai dengan dinamika sosial dan ekonomi masyarakat dalam rangka mewujudkan pemerataan pelayanan sosial perkotaan yang adil sesuai dengan tingkatan kelompok masyarakat. Metode yang digunakan adalah metode survei dengan basis analisis data sekunder yang didukung oleh data hasil observasi lapangan serta perbandingan secara antar waktu (time series). Teknik analisis menggunakan statistik deskriptif kualitatif dan kuantitatif. Hasil penelitian menunjukkan bahwa ada tiga strategi yang dapat digunakan yaitu strategi kemitraan, strategi pemberdayaan dan strategi penguatan kelembagaan, sedangkan rencana aksi pengembangannya dirumuskan kedalam program kemitraan antara pemerintah pusat dan daerah, pemda dengan swasta, pemda dengan masyarakat; progam kemitraan tersebut juga dapat dilaksanakan melalui mekanisme fasilitasi pemda terhadap masyarakat dan swasta; program pemberdayaan dan program penguatan kelembagaan dan sumberdaya manusia dengan rencana aksi meliputi pengkajian kebijakan dan penyusunan rencana pelayanan sosial, Pengembangan model pelayanan sosial, pembentukan dan pengembangan sistem informasi, basis data serta jaringan kerja
\end{abstract}

Kata Kunci: strategi, rencana aksi dan pelayanan sosial perkotaan 


\section{Pendahuluan}

Kota Jakarta dengan berbagai keunggulan komparatif dan kompetitifnya memiliki posisi yang sangat penting dan strategis dalam pembangunan nasional. Kota Jakarta berperan sebagai pusat pelayanan baik dalam skala nasional maupun internasional. Hal ini tidak terlepas dari fungsi DKI sebagai ibukota negara, pusat perdagangan dan distribusi, pusat keuangan, pusat pariwisata dan pusat pembangunan masyarakat, pusat ilmu pengetahuan teknologi, pengembangan pendidikan dan kebudayaan serta pusat pengembangan politik.

Sehubungan dengan peran dan fungsi tersebut, Kota Jakarta dituntut untuk terus meningkatkan pelayanannya kepada seluruh lapisan masyarakat. Pelayanan jasa perkotaan tersebut pada hakekatnya merupakan tanggung jawab pemerintah kota. Jenis pelayanan perkotaan dapat berupa penyediaan fasilitas umum dan sosial yang memadai, penyuluhan teknis, penyantunan/rehabilitasi sosial, pelayanan administrasi dan penyampaian informasi pembangunan kepada ma3, arakat. Pelayanan tersebut perlu diti. satkan baik itu dalam penyedian prasara dan sarana, prosedur maupun tata cara pelaksanaannya agar lebih efisien dan efektif. Selain itu kecermatan dalam memberikan pelayanan agar ditujukan untuk kepuasan seluruh lapisan masyarakat.

Masyarakat perkotaan yang dimaksud adalah masyarakat kota Daerah Khusus Ibukota Jakarta. Pengertian formal tentang Pelayanan Sosial, sesuai yang diamanatkan dalam PPIMN 2005-2009, yaitu pelayanan vang diberikan oleh Fonerintah (Daere un- tuk mewujudkan keadilan sosial secara nyata melalui redistribusi hasil-hasil pembangunan yang dicapai, bagi penduduk miskin, marginal dan rentan.

Komponen-komponen Pelayanan Sosial Perkotaan (Urban Social Services), menurut beberapa literatur, meliputi : Kesehatan (health \& nutrition); Pendidikan dan ketrampilan (education \& training program); Pendapatan / penghasilan (income security \& basic income support); Perumahan (housing); Keamanan (personal safety \& crime prevention); Penanggulangan keadaan darurat (emergency assistance); Jaminan Sosial (social security).

Hal ini penting mengingat kegiatan pelayanan sosial perkotaan tidak akan terwujud tanpa peran serta masyarakat dan kesungguhan pemerintah. Oleh karenanya, diperlukan suatu strategi dan rencana aksi pengembangan pelayanan sosial perkotaan (Urban Social Services) dalam rangka meningkatkan daya dukung kawasan di Wilayah DKI Jakarta.

Penulisan tentang Strategi dan Rencana Aksi Pengembangan Urban Social Services dimaksudkan untuk merumuskan strategi dan rencana tindak yang komprehensif dan berkelanjutan dalam rangka untuk mengembangkan dan meningkatkan daya dukung kawasan di Wilayah DKI Jakarta.

Adapun tujuannya adalah :

1. merumuskan strategi pengembangan fasilitas pelayanan sosial perkotaan sesuai dengan dinamika sosial dan ekonomi masyarakat di wilayah DKI Jakarta

2. menyusun Rencana aksi pengembangan pelayanan sosial perkotaan di Wilayah DKI Jakarta. 


\section{Metode}

Langkah-langkah yang dilakukan dalam pelaksanaan pekerjaan adalah sebagai berikut:

a. Melakukan kajian kepustakaan seputar pengertian urban sosial service, faktor-faktor penyebab kesenjangan terhadap pelayanan sosial perkotaan, dan konsep-konsep pengembangan pelayanan sosial perkotaan.

b. Melakukan inventarisasipermasalahan yang terjadi di dalam perkembangan sosial di Jakarta yang terkait dengan kebutuhan pelayanan sosial melalui media informasi dan kajian literatur.

c. Menginventarisir kebijakan pengembangan kesejahteraan sosial perkotaan di DKI Jakarta melalui Renstrada, RTRW maupun dan peraturan daerah lainnya..

d. Menganalisis permasalahan dan perkembangan kota kemudian selanjutnya dilakukan analisis faktor-faktor penyebab permasalahan pengembangan pelayanan sosial perkotaan, hasil dari analisis ini digunakan sebagai masukan dalam analisis terhadap kebutuhan akan pelayanan sosial perkotaan.

e. Melakukan analisis kebutuhan pengembangan pelayanan sosial perkotaan yang sesuai dengan permasalahan, analisis ini dilakukan berdasarkan pada hasil penelahaan terhadap program-program kesejahteraan sosial yang terkait dengan peningkatan pelayanan sosial perkotaan.

\section{Hasil dan Pembahasan}

\section{Jumlah, Pertumbuhan dan Kepa- datan Penduduk}

Pada tahun 1980 jumlah penduduk kota Jakarta sebanyak 6,5 juta jiwa dan meningkat pada tahun 1990 sebanyak 8,22 juta jiwa atau mengalami kenaikan jumlah penduduk sebesar 172,5 ribu jiwa. Kenaikan ini nampaknya cukup besar jika dibandingkan dengan jumlah penduduk tahun 1990 sampai dengan tahun 2000 yang meningkat hanya sebesar 133 ribu jiwa atau dengan jumlah keseluruhan sebesar 8,36 juta jiwa. Di tahun 2004 jumlah penduduk Kota Jakarta naik hingga mencapai 9,04 juta jiwa atau mengalami kenaikan dari tahun 2000 sebesar 681 ribu jiwa. Jumlah penduduk Kota Jakarta pada tahun 2005 sebesar 9,04 juta, dan ini artinya jumlah penduduk kota Jakarta dari tahun ke tahun terus bertambah. Dengan makin meningkatnya jumlah penduduk tersebut menimbulkan dampak sosial yang kompleks.

Laju pertumbuhan penduduk Tahun 2000-2005 berdasarkan wilayah kota, Kota Jakarta Pusat memiliki laju pertumbuhan negatif artinya terjadi perpindahan penduduk dari wilayah tersebut ke wilayah lain. Kota Jakarta Pusat bahkan memperlihatkan penurunan jumlah penduduk yang cukup signifikan dalam 20 tahun terakhir.

Pertumbuhan penduduk pada periode 1990 - 2005 terjadi di semua kota di DKI Jakarta, tetapi dengan laju pertumbuhan penduduk yang berbedabeda. Laju pertumbuhan penduduk tertinggi terjadi di Jakarta Barat $(4,03$ persen), diikuti oleh Jakarta Selatan 
(2,21 persen), Jakarta Timur ( 0,34 persen) dan Jakarta Utara $(0,34$ persen). Sementara itu Jakarta Pusat memiliki laju pertumbuhan penduduk yang negatif, masing masing sebesar $-0,72$ persen. Ini berarti bahwa pada kota ini mengalami penurunan jumlah penduduk. Pengembangan permukiman dalam kota di wilayah barat, dan selatan disertai dengan pengembangan sektor industri menjadi daya tarik pendatang untuk tinggal di wilayah tersebut, sehingga wajar jika pertumbuhan penduduk kedua kota ini merupakan yang tertinggi. Penurunan jumlah penduduk yang terjadi di Kota Jakarta Pusat karena banyak penduduk yang akhirnya pindah ke wilayah lain karena lahan tempat tinggal mereka banyak yang dipindahtangankan dan dialihkan untuk kegiatan bisnis dan perkantoran.

Dengan luas wilayah yang tetap yaitu hanya sebesar $661,62 \mathrm{~km} 2$, sementara jumlah penduduk DKI Jakarta terus mengalami peningkatan maka dapat dipastikan bahwa kepadatan penduduk di DKI Jakarta akan terus meningkat. Pada tahun 1990 kepadatan penduduk DKI Jakarta mencapai 12.484 jiwa per km2, pada tahun 2005 meningkat menjadi 13.688 jiwa per km2. Peningkatan kepadatan penduduk tersebut terjadi di hampir seluruh kotakecuali Kota Jakarta Pusat.

\section{Arus Migrasi Masuk Ke DKI Jakarta}

Proses perubahan sosial tersebut diatas adalah semakin menggelembungnya aktivitas kegiatan sosial ekonomi di sektor informal serta membengkaknya jumlah pengangguran terbuka di wilayah DKI Jakarta. Dampak lainnya antara lain menjamurnya penyandang masalah sosial (tuna wisma, anak jalanan, penyandang narkoba, prostitusi dan perjudian) serta tentu saja terjadinya peningkatan kriminalitas dan degradasi fungsi lingkungan serta menjamurnya wilayah kumuh yang masih saja tetap semarak di wilayah metropolitan ini.

\section{Gambar 1 Migrasi Masuk Ke DKI Jakarta Tahun 1975-2005}

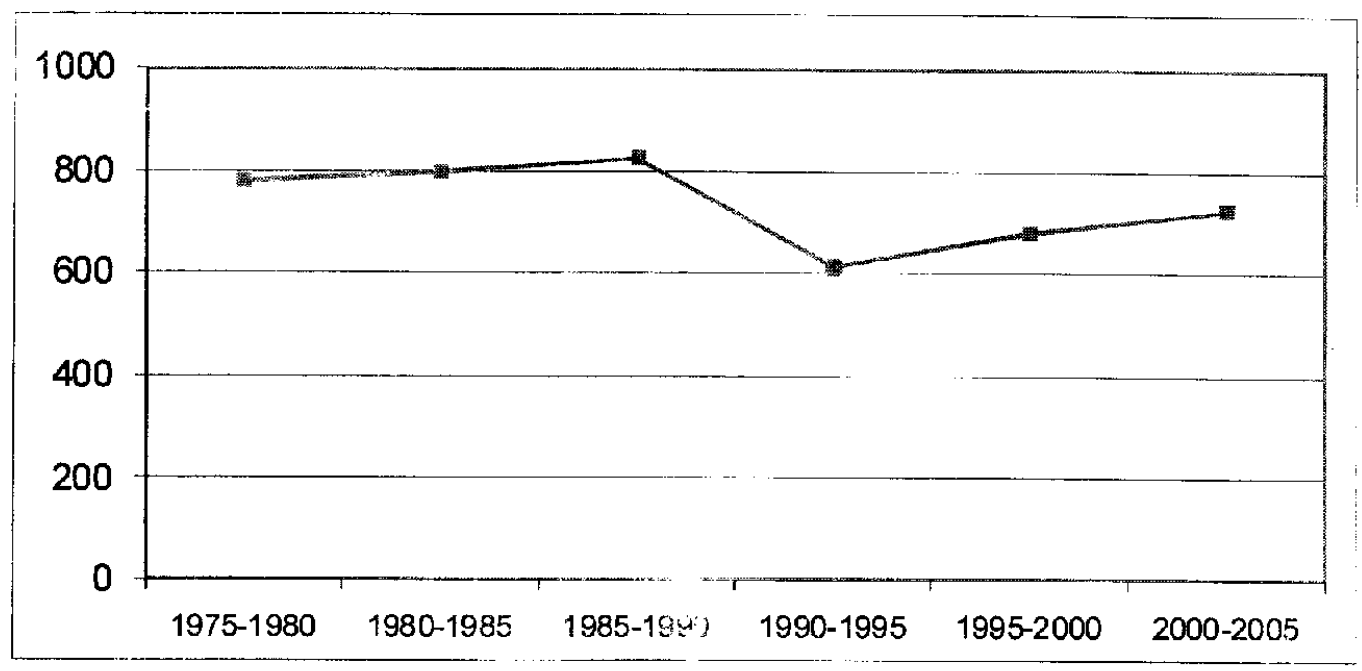

sm or:Diolain Dari DataBPS 
Dari grafik diatas dapat diamati bahwa pada periode Tahun 1995 sampai dengan tahun 2005, migrasi masuk ke wilayah DKI Jakarta nampaknya telah meningkat kembali dengan besaran yang cukup mengkhawatirkan karena sebelumnya pada rentang waktu antara tahun 1985 hingga tahun 1990 jumlahnya mengalami penurunan.

\section{Populasi Penyandang Masalah Kes- ejahteraan Sosial}

Populasi Penyandang Masalah Kesejahteraan Sosial (PMKS) di Provinsi DKI Jakarta Tahun 2005 berjumlah 69.629 orang. Jumlah tersebut mengalami penurunan jika dibandingkan tahun-tahun sebelumnya yaitu pada tahun 2004 sebanyak 72.309 orang dan tahun 2003 sebanyak 71.955 orang. Penurunan angka tersebut nampaknya masih kurang signifikan karena hanya turun sekitar 4,8 persen dari tahun sebelumnya.

Namun penurunanjumlahPMKS secara keseluruhan tersebut nampaknya tidak terjadi secara merata di tiap Kota
DKI Jakarta. Masih terdapat beberapa kota dengan jumlah PMKS yang semakin bertambah antara lain di Jakarta Timur dengan jumlah sebanyak 25.111 orang pada tahun 2004 menjadi 25.426 orang di tahun 2005. Dengan jumlah PMKS sebanyak itu maka menjadikan Jakarta Timur sebagai wilayah dengan populasi PMKS terbesar di wilayah DKI Jakarta. Selain Jakarta Timur, wilayah yang jumlah populasi PMKS makin bertambah yaitu Jakarta Barat dengan jumlah PMKS 9.613 orang pada tahun 2004 menjadi 9.698 orang pada tahun 2005, dan Jakarta Utara dari jumlah PMKS sebanyak 11.342 orang di tahun 2004 meningkat menjadi 12.533 orang di tahun 2005.

Jenis PMKS dengan populasi terbanyakadalahAnakTerlantarsebesar 15.464 orang atau 22,21 persen, Lansia Terlantar sebesar 14.416 orang atau 20,70 persen dan Penyandang Cacat sebesar 12.704 orang atau sebesar 18,24 persen. Wilayah yang dari ketiga jenis PMKS tersebut paling banyak populasinya nampaknya berada di wilayah Kota Jakarta Timur.

\section{Gambar 2 Kontribusi Jumlah PMKS Terhadap Jumlah Penduduk Menurut Kota Tahun 2005}

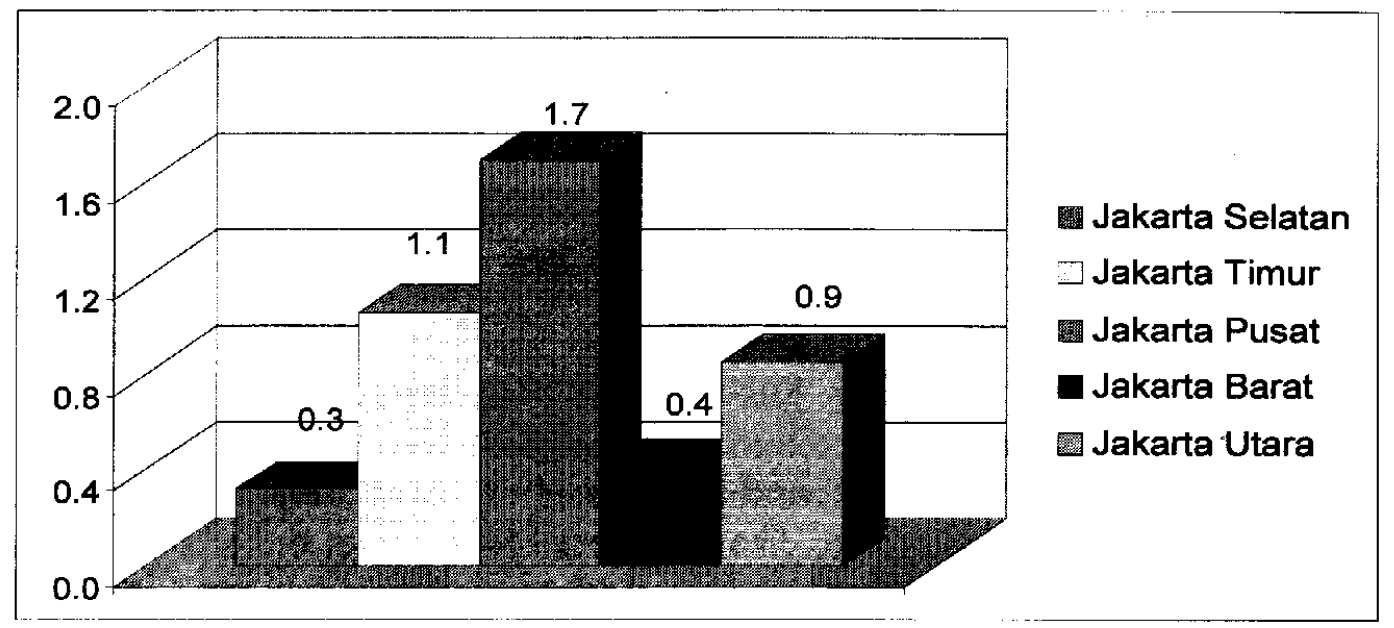

Sumber: Hasil Olahan, 2006 
Kontribusi jumlah PMKS terbesar terhadap jumlah penduduk terjadi di Kota Jakarta Pusat sebesar 1,7 persen. Selanjutnya diikuti oleh Kota Jakarta Timur (1,1 persen); Kota Jakarta Utara $(0,9$ persen); Kota Jakarta Barat $(0,4$ persen) dan yang terendah berada di Kota Jakarta Selatan sebesar 0,3 persen.

Jenis Potensi dan Sumber Kesejahteraan Sosial (PSKS) pada tahun 2005 mengalami peningkatan dibanding dengan tahun sebelumnya. Jika pada tahun 2004 jumlah PSKS sebesar 16.421 orang maka pada tahun 2005 jumlahnya meningkat menjadi 19.405 orang. Namun peningkatan PSKS tersebut hanya terjadi pada Pekerja Sosial Masyarakat dimana pada tahun 2004 jumlahnya sebesar 1.802 orang, dan mengalami peningkatan pada tahun 2005 sebesar 4.786 orang pekerja. Sedangkan untuk jenis PSKS lainnya seperti Pengurus Karang Taruna, Pengurus Pokja Kesuma dan Pengurus Orsos/Badan Sosial nampaknya tidak mengalami peningkatan. Meskipun demikian dapat dikatakan bahwa telah terjadi peningkatan peranserta sosial masyarakat baik itu secara jumlah dan kualitas Tenaga Kerja Sosial Masyarakat (TKSM) dan Orsos/LSM yang berperan aktif dalam memberikan pelayanan social di Provinsi DKI Jakarta.

\section{Gambar 3 Jumlah PMKS Terhadap Jumlah Warga Binaan Sosial (WBS) Menurut Kota Tahun 2005}

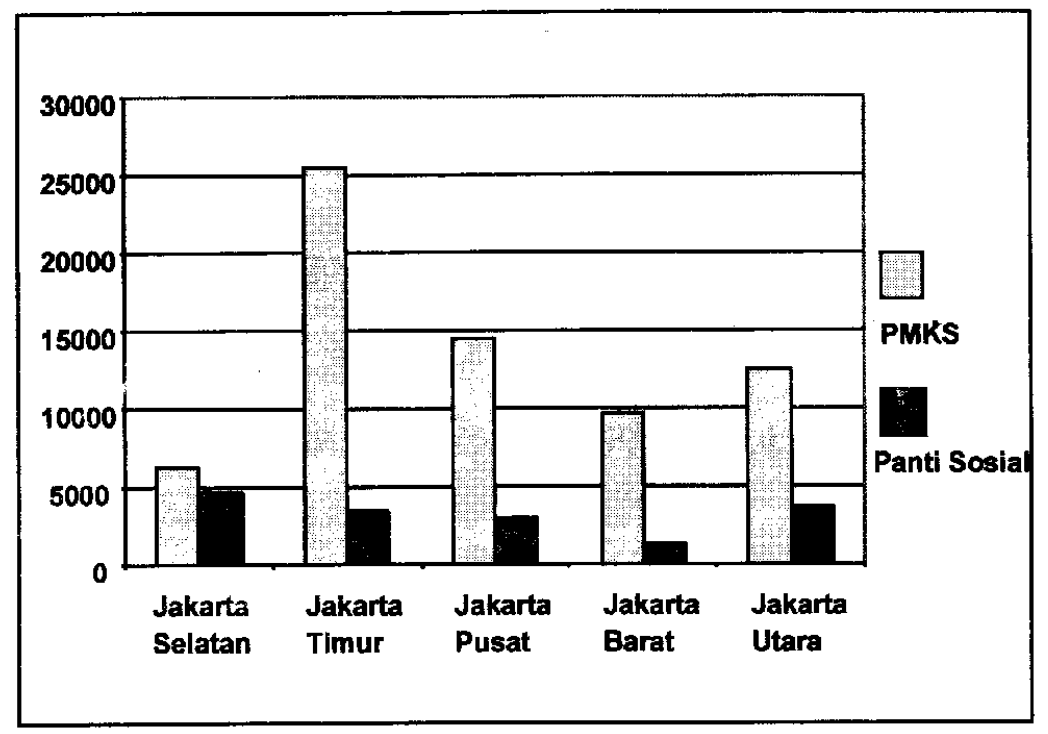

Sumber:Hasil Olahan, 2006

Jenis Potensi dan Sumber Kesejahteraan Sosial (PSKS) pada tahun 2005 mengalami peningkatan dibanding dengan tahun sebelumnya. Jika pada tahun 2004 jumlah PSKS sebesar 16.421 orang maka pada tahun 2005 jumlahnya meningkat menjadi 19.405 orang. Namun peningkatan PSKS tersebut hanya terjadi pada Pekerja Sosial Masyarakat dimana pada tahun 2004 jumlahnya sebesar 1.802 orang, dan mengalami peningkatan pada ta- 
hun 2005 sebesar 4.786 orang pekerja. Sedangkan untuk jenis PSKS lainnya seperti Pengurus Karang Taruna, Pengurus Pokja Kesuma dan Pengurus Orsos/Badan Sosial nampaknya tidak mengalami peningkatan. Meskipun demikian dapat dikatakan bahwa telah terjadi peningkatan peranserta sosial masyarakat baik itu secara jumlah dan kualitas Tenaga Kerja Sosial Masyarakat (TKSM) dan Orsos/LSM yang berperan aktif dalam memberikan pelayanan social di Provinsi DKI Jakarta.

Panti Sosial milik Swasta/Masyarakat sangat membantu pemerintah di dalam penanganan PMKS. Kondisi Panti Sosial milik Masyarakat/swasta pada tahun 2005 nampaknya mengalami peningkatan yang cukup besar jika dibandingkan dengan kondisi jumlah Panti Sosial pada tahun sebelumnya. Jika pada tahun 2004 warga binaan yang ada di DKI Jakarta sebesar 12.616 orang dengan 181 unit maka pada tahun 2005 mengalami peningkatan yang cukup besar atau hampir mencapai dua kali lipat dari tahun sebelumnya yaitu sebesar 22.688 warga binaan dengan 261 unit. Panti Sosial Asuhan Anak merupakan lembaga social yang paling besar mengalami peningkatan. Jika pada tahun 2004 jumlah warga binaannya sebesar 5.263 orang dan dengan 77 unit maka pada tahun 2005 jumlahnya meningkat menjadi 14.338 orang warga binaan dengan 261 unit panti sosial. Begitu pula halnya dengan jumah panti Sosial Pusat Santunan Dalam Keluarga (Pusaka) yang juga mengalami peningkatan. Jika pada tahun 2004 jumlah warga binaan sebesar 4.661 dengan 73 unit maka pada tahun 2005 jumlahnya meningkat menjadi menjadi 6.363 warga binaan dengan 102 unit panti social.
Berbeda halnya dengan kondisi Panti social Tresna Werdha yang mengalami penurunan jumlah. Jika pada tahun 2004 jumlahnya sebesar 12 unit dengan jumlah warga binaan sebanyak 965 orang maka pada tahun 2005 mengalami penurunan sebesar 7 unit dan dengan warga binaan sebanyak 260 orang. Nampaknya lembaga social yang jumlahnya tidak mengalami perubahan adalah jenis Panti Sosial Penyandang Cacat dengan keseluruhan warga binaan sebesar 1.727 orang dan dengan jumlah unit sebesar 19 panti sosial. Jenis lembaga pelayanan kesejahteraan sosial dengan jumlah warga binaan terbanyak adalah dari jenis Non Panti Sosial sebanyak 25.715 orang. Sedangkan jumlah lembaga pelayanan yang terbanyak unitnya adalah Panti Pijat Tuna Netra (Papitun) sebesar 190 unit. Jumlah lembaga pelayanan kesejahteraan sosial milik masyarakat/swasta tahun 2005 sebesar 56.080 orang yang mana mengalami peningkatan yang cukup signifikan dari tahun 2004 yang mana berjumlah 35.608 orang. Namun jika dibandingkan antara jumlah tahun 2004 dengan tahun 2003 nampaknya mengalami penurunan jumlah. Keberadaan Sasana Krida Karang Taruna (SKKT) sebagai lembaga organisasi kepemudaan yang pembinaannya sepenuhnya dilakukan oleh Pemerintah sangatlah penting. Jumlah SKKT yang asetnya merupakan milik Dinas Sosial dan Kota hampir sama besar banyaknya. Jika aset Kota sebanyak 150 buah maka aset Dinas Sosial sebanyak 138 buah dan secara keseluruhan SKKT di DKI Jakarta berjumlah 288 buah. Dilihat dari perkembangan SKKT pada tahun sebelumnya maka mengalami peningkatan jumlah. Namun sangat disayangkan bahwa ternyata jumlah SKKT sejak dari tahun 
2001 sampai 2003 mengalami penurunan dan kembali meningkat mulai tahun 2004 yang jumlahnya pun sama besar dengan tahun 2005 yaitu sebanyak 288 buah.

\section{Penduduk Miskin}

Angka kemiskinan di Provinsi DKI Jakarta dari tahun ke tahun terus meningkat. Pada Tahun 2004, jumlah penduduk miskin berjumlah 370.898 jiwa atau sebesar 4 persen dari total penduduk DKI Jakarta yang berjumlah sekitar 9 juta orang. Pada tahun 2005 jumlah penduduk miskin meningkat menjadi 633.212 jiwa atau sebesar 7 persen dari total penduduk dan dengan jumlah rumah tangga miskin yang mencapai 150.492 rumah tangga. Rumah tangga miskin terbanyak terdapat di Kota Jakarta Utara, yakni sebanyak 48.254 rumah tangga $(32,5 \%)$, diikuti Jakarta Timur sebanyak 38.738 rumah tangga $(25,7 \%)$, Jakarta Barat 29.328 rumah tangga $(19,4 \%)$, Jakarta Pusat 21.968 rumah tangga $(14,1 \%)$, dan Jakarta Selatan 11.162 rumah tangga $(7,6 \%)$. Sedangkan untuk wilayah Kepulauan Seribu jumlah rumah tangga miskin hanya sebesar 1.042 rumah tangga $(0,6 \%)$. Jumlah penduduk miskin yang cukup besar ini tentu saja menimbulkan berbagai permasalahan antara lain dari segi pendidikan dan kriminalitas. Kota Jakarta Utara merupakan wilayah dengan kontribusi penduduk miskin terbesar terhadap jumlah penduduknya yaitu sebesar 14,0 persen. Untuk selanjutnya ditempati oleh Kota Jakarta Pusat $(10,4 \%)$; Kota Jakarta Timur $(6,8 \%)$; Kota Jakarta Barat $(5,3 \%)$ dan yang terendar adalah Kota Jakarta $5 \%$ atan sebesar 2,4 persen
Pemprov DKI juga telah menganggarkan kartu Jaring Pengaman Kesehatan (JPK) Gakin sebesar Rp200 miliar untuk 565.982 jiwa penduduk, 116 buah panti sosial dan 35 buah rumah singgah. Selain itu disediakan pula fasilitas berobat gratis di 80 rumah sakit.

Faktor-faktor yang berpengaruh terhadap Aspek Pelayanan Sosial dan Aspek Lingkungan Strategis

Faktor-faktor yang mempengaruhi aspek Pelayanan Sosial Perkotaan, Propinsi Daerah Khusus Ibukota Jakarta Raya (DKI Jaya), meliputi:

- Pelaku Pelayanan Sosial Perkotaan:

- Fasilitas (sarana \&prasarana):

- Obyek Pelayanan

- Pengelolaan Faktor-faktor yang mempengaruhi aspek Lingkungan Strategis, pelayanan sosial perkotaan Daerah Khusus Ibukota Jakarta Raya

Berdasarkan data dan analisis diatas, pembangunan dan pengembangan pelayanan kesejahteraan sosial Jakarta ke depan akan mencakup variasi dan konfigurasi permasalahan sosial serta potensi dan sumber kesejahteraan sosial (modal sosial), yaitu :

a. Variasi dan konfigurasi permasalahan sosial perkotaan

(1) Kemiskinan

Warga atau masyarakat yang menyandang ketidakmampuan sosial ekonomi atau warga yang rentan menjadi miskin seperti: keluarga fakir miskin; dan keluarga rawan sosial ekonomi. Termasuk warga yang tinggal dipermukiman kumuh (slum area), dan pemukim pe- 


\begin{tabular}{|c|c|c|c|c|}
\hline \multirow[b]{2}{*}{ KOMPONEN } & \multicolumn{2}{|c|}{ NTTERNAL } & \multicolumn{2}{|r|}{ EKSTERNAL } \\
\hline & $\begin{array}{r}\text { STRENGTH } \\
\text { (S) } \\
\end{array}$ & $\begin{array}{l}\text { WEAKNESESS } \\
(\boldsymbol{W})\end{array}$ & $\begin{array}{l}\text { OPPORTUNITY } \\
\text { (O) }\end{array}$ & $\begin{array}{c}\text { THREAT } \\
\text { (T) }\end{array}$ \\
\hline \multicolumn{5}{|c|}{ 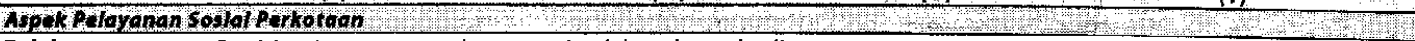 } \\
\hline $\begin{array}{l}\text { Pelaku } \\
\text { Pelayanan } \\
\text { Soslal } \\
\text { Perkotaan }\end{array}$ & 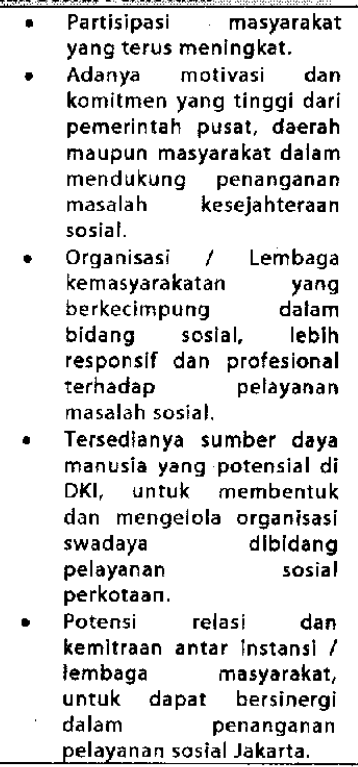 & $\begin{array}{l}\text { Jumlah dan kualitas } \\
\text { pekerja sosial yang } \\
\text { belum memadai (belum } \\
\text { proporsional), untuk } \\
\text { menjalankan tugas } \\
\text { pelayanan sosial } \\
\text { perkotaan. } \\
\text { Koordinasi antar unit } \\
\text { kerja yang terkait masih } \\
\text { lemah } \\
\text { Pemenuhan tanggung } \\
\text { jawab sosial oleh swasta } \\
\text { (perusahaan) kurang } \\
\text { termonitor dengan baik } \\
\text { sehingga tidak optimal. }\end{array}$ & - & $\begin{array}{l}\text { - Krisis ekonomi dan politik, } \\
\text { dapat mengancam pelaku- } \\
\text { pelaku pelayanan sosial, untuk } \\
\text { dapat meneruskan tugas } \\
\text { kerjanya. }\end{array}$ \\
\hline Pendanaan & $\begin{array}{l}\text { - Rasa kesetiakawanan dan } \\
\text { potensi bantuan } \\
\text { masyarakat sekitar yang } \\
\text { sangat responsif terhadap } \\
\text { penanggulangan bencana. } \\
\text { - Patensi dana masyarakat } \\
\text { yang tersalurkan lewat } \\
\text { berbagal lembaga, dalam } \\
\text { mengatasi masalah- } \\
\text { masalah sosial kota. } \\
\text { Komitmen dan peraturan / } \\
\text { regulasl yang menjamin } \\
\text { pemerintah } \\
\text { mengalokasikan } \\
\text { dibidang sosial. } \\
\text { Kemampuan ekonomi lokal } \\
\text { Jakarta, adalah yang paling } \\
\text { besar diantara daerah lain. }\end{array}$ & $\begin{array}{l}\text { - Terbatasnya anggaran } \\
\text { daerah untuk } \\
\text { penanganan pelayanan } \\
\text { sosial masyarakat. } \\
\text { Monltoring anggaran } \\
\text { swasta (perusahaan) } \\
\text { yang dialokasikan } \\
\text { sebagai tanggung jawab } \\
\text { sosiai perusahaan, masih } \\
\text { lemah dan kurang } \\
\text { terkoordinasl dengan } \\
\text { bidang yang terkait. } \\
\text { Pengelolaan dan } \\
\text { penyaluran dana-dana } \\
\text { masyarakat untuk } \\
\text { fungsi-fungsi pelayanan } \\
\text { sosial kurang baik dan } \\
\text { belum optimal. } \\
\text { Pemanfaatan dan alokasi } \\
\text { program dalam rangka } \\
\text { pelayanan sosial yang } \\
\text { kurang terkontrol dan } \\
\text { terawasi dengan baik } \\
\text { mengakibatkan program } \\
\text { tersebut menjadi tidak } \\
\text { tepat sasaran. }\end{array}$ & $\begin{array}{l}\text { Tersedianya } \\
\text { berbagal } \\
\text { alternatif } \\
\text { pemblayaan } \\
\text { pelayanan } \\
\text { sosla! } \\
\text { perkotaan } \\
\text { oleh } \\
\text { Pemerintah } \\
\text { Pusat } \\
\text { maupun dari } \\
\text { luar negeri } \\
\text { (GO maupun } \\
\text { NGO). }\end{array}$ & $\begin{array}{l}\therefore \\
\therefore\end{array}$ \\
\hline Fasilitas & $\begin{array}{l}\text { - Legalitas dan Regulasi } \\
\text { yang mendukung / } \\
\text { mempermudah } \\
\text { penyediaan sarana dan } \\
\text { prasarana untuk kegiatan } \\
\text { sosial. } \\
\text { - Struktur pemerintahan } \\
\text { yang jelas, dapat } \\
\text { dimanfaatkan sebagai } \\
\text { agen penyediaan } / \\
\text { peiaksana pelayanan sosial } \\
\text { perkotaan. }\end{array}$ & $\begin{array}{l}\text { - Jenis dan macam } \\
\text { fasilitas pelayanan sosial } \\
\text { yang tersedla, belum } \\
\text { memenuhi kebutuhan } \\
\text { pelayanan sosial } \\
\text { perkotaan jakarta. } \\
\text { Kapasitas dan distribusi } \\
\text { fasilitas yang tersedia, } \\
\text { belum optimal / belum } \\
\text { merata (sesual dengan } \\
\text { konsentrasl } \\
\text { permasalahan sosial } \\
\text { kota). } \\
\text { Data hasil pelaksanaan } \\
\text { program dan data } \\
\text { penunjang belum dapat } \\
\text { terdokumentasi dan } \\
\text { terekam secara baik dan } \\
\text { akses memperoleh } \\
\text { informasi yang berkaitan } \\
\text { dengan keberadaan, } \\
\text { persebaran son } \\
\text { permasalahan } \\
\text { kesejahteraan sosial } \\
\text { serta kemampuan } \\
\text { potensi dan sumber } \\
\text { kesejahteraan sosial } \\
\text { jugamasih terbatas. }\end{array}$ & - & 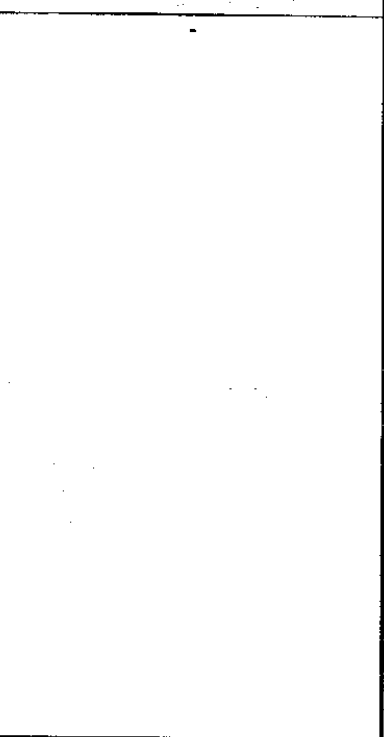 \\
\hline
\end{tabular}




\begin{tabular}{|c|c|c|c|c|c|}
\hline $\begin{array}{l}\text { Obyok } \\
\text { Polayunan }\end{array}$ & 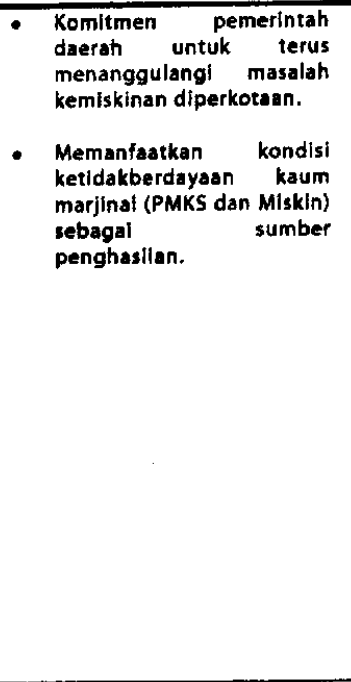 & $\begin{array}{l}\text { - Resistensi kelompok ' } \\
\text { golongan PMKS, } \\
\text { mempersulit upaya } \\
\text { pelayanan sosial yang } \\
\text { akan diberikan. } \\
\text { - Ketrampilan, pendidikan } \\
\text { dan kondisi SDM obyek } \\
\text { yang rendah. }\end{array}$ & $\begin{array}{l}\text { - lkaten } \\
\text { emosional, } \\
\text { kesetiakawan } \\
\text { an, rasa } \\
\text { senaslb yang } \\
\text { tinggi pada } \\
\text { kaum } \\
\text { marjlnal atau } \\
\text { korban } \\
\text { bencana, } \\
\text { dapat } \\
\text { digunakan } \\
\text { sebagal jalur } \\
\text { pelayanan } \\
\text { pembinaan } \\
\text { soslal. } \\
\text { Potensi } \\
\text { perbaikan } \\
\text { kesejahterasn } \\
\text { masyarakat } \\
\text { kota, melalul } \\
\text { penanganan } \\
\text { kaum } \\
\text { marjlnal dan } \\
\text { korban } \\
\text { bencana. }\end{array}$ & & $\begin{array}{l}\text { Krisis dan Instabilitas berbagai } \\
\text { bidang, menyebabkan terus } \\
\text { bertambahnya obyek (kaum } \\
\text { marjinal). }\end{array}$ \\
\hline Pengelolaen & 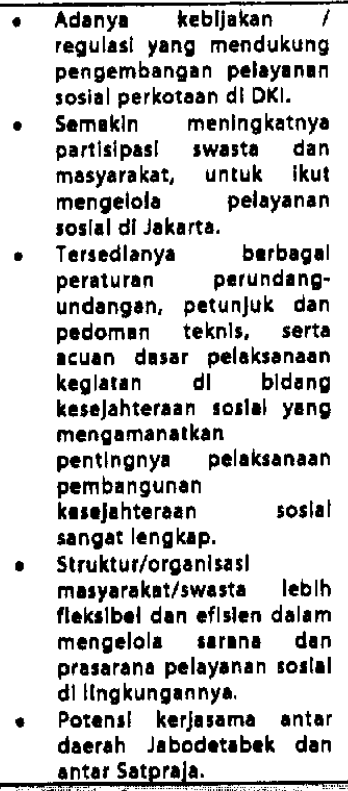 & $\begin{array}{l}\text { - Implementasi atas } \\
\text { kebijakan serlng kali } \\
\text { lidak dilkutl dengan } \\
\text { pengawasan dan } \\
\text { evaluasl, sehingga } \\
\text { pengembangan sistem } \\
\text { pelayanan soslal kurang } \\
\text { efektlf dan tidak eflsien. } \\
\text { Kurang efektlfnya } \\
\text { pengelolaan dalam } \\
\text { bentuk kerjasama antar } \\
\text { wllayah dan unit yang } \\
\text { terkait. }\end{array}$ & $\begin{array}{l}\text { - Porsl } \\
\text { pengelolaan } \\
\text { dan Jenis } \\
\text { pelayanan } \\
\text { sosial dapat ' } \\
\text { memungkink } \\
\text { on diserahkan } \\
\text { lebih banyak, } \\
\text { kepada atau } \\
\text { swasta atau } \\
\text { masyarakat. } \\
\text { Adanya } \\
\text { potensl kerja } \\
\text { sama antar } \\
\text { bidang dan } \\
\text { ontar } \\
\text { pamerintah } \\
\text { daerah } \\
\text { sekitar } \\
\text { Jakarta daiam } \\
\text { penanganan } \\
\text { masalah } \\
\text { sosial. }\end{array}$ & $\bullet$ & $\begin{array}{l}\text { Sinergl den keterpaduan lintas } \\
\text { sektor/program dan jaringan } \\
\text { kerja dalam pelaksanaan } \\
\text { program/kegiatan khususnya } \\
\text { dalam menangani } \\
\text { permasalahan kesejahteraan } \\
\text { sosial dan merespon maupun } \\
\text { mengantislpasi perubahan } \\
\text { issue strategls di berbagal } \\
\text { sektor masih belum optlmal. }\end{array}$ \\
\hline \multicolumn{6}{|c|}{ 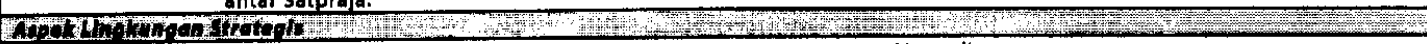 } \\
\hline $\begin{array}{l}\text { Komlemen } \\
\text { Naslonal dan } \\
\text { Interneslonal }\end{array}$ & $\begin{array}{l}\text { Telah diratlfikasinya } \\
\text { beberapar komitmen } \\
\text { Internaslonal tentang } \\
\text { HAM, Hak Sosial Dasar dan } \\
\text { sebaginya. }\end{array}$ & 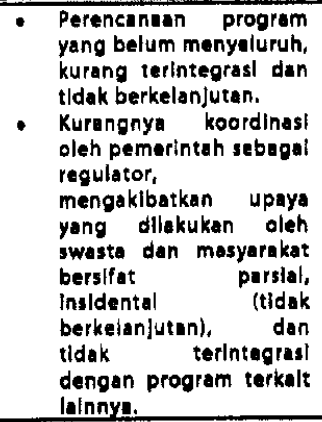 & $\begin{array}{l}\text { Mengalirnya } \\
\text { bantuan- } \\
\text { bantusen } \\
\text { asing GO } \\
\text { maupun NGO, } \\
\text { berkaltan } \\
\text { dengan } \\
\text { massiah- } \\
\text { maselah } \\
\text { sosial dl } \\
\text { Indonesia. }\end{array}$ & & 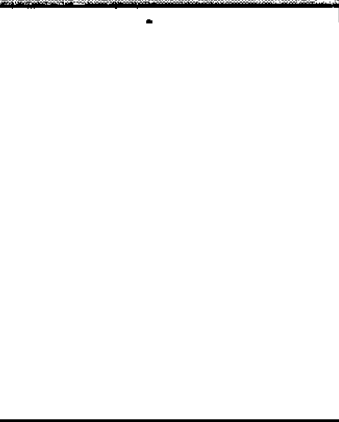 \\
\hline $\begin{array}{l}\text { Daye Torik } \\
\text { Kote Jekarte }\end{array}$ & $\begin{array}{l}\text { - Sabagal Ibukota Negara } \\
\text { dan Pomerintahan, DKI } \\
\text { Jaya memilki sarana dan } \\
\text { prasaran yang paling } \\
\text { lengkap dlbanding doerah } \\
\text { lainnyu. } \\
\text { Jakarta sobagal pusat } \\
\text { perekonomlam naslonal, } \\
\text { pusat peloyanan din pusat } \\
\text { informasl }, \text { data } \\
\text { sumberdoya. }\end{array}$ & $\begin{array}{l}\text { Heterogenitas penduduk } \\
\text { mengaklbatkan } \\
\text { kompleksnya } \\
\text { permesulahan sosial } \\
\text { kota. }\end{array}$ & $\cdot$ & $\bullet$ & $\begin{array}{l}\text { Arus urbanisasi dan kamuter } \\
\text { (penglaju), } \\
\text { meningkatkan berpotensi } \\
\text { penduduk morjinal dumlah } \\
\text { memperparah masalah sosial } \\
\text { kota dakarta. }\end{array}$ \\
\hline
\end{tabular}


nyerobot (squatter) karena ketidak mampuan mereka menyediakan papan yang layak.

(2) Keterlantaran

Warga atau masyarakat yang karena sesuatu hal mengalami keterlantaran fisik, mental dan sosial, seperti: balita terlantar, anak dan remaja terlantar, termasuk anak jalanan dan pekerja anak, orang dewasa terlantar, keluarga bermasalah sosial psikologis, dan lansia terlantar.

(3) Ketunaan sosial dan penyimpangan perilaku

Warga atau masyarakat yang mengalami gangguan fungsifungsi sosialnya akibat ketidakmampuannya mengadakan penyesuaian (social adjusment) secara normatif, seperti: tuna susila, anak konflik dengan hukum/ nakal, bekas narapidana, korban narkotika, gelandangan; pengemis dan korban HIV/AIDS dan eks penyakit kronis terlantar.

(4) Kecacatan

Warga atau masyarakat yang mengalami kecacatan fisik dan mental sehingga terganggu fungsi sosialnya, seperti: cacat veteran, cacat tubuh, cacat mental, tuna netra, tuna rungu wicara dan cacat bekas penderita penyakit kronis.

(6) Korban Bencana

Warga dan masyarakat yang mengalami musibah atau bencana, seperti: korban bencana alam, kebakaran, kebanjiran dan korban bencana sosial yang disebabkan oleh konflik sosial

(7) Korban Tindak Kekerasan, Eksploitasi dan Diskriminatif, meliputiwargamasyarakatyang mengalami tindak kekerasan, seperti: anak yang dilacurkan, diperdagangkan dan bekerja dalam situasi terburuk, wanita korban tindak kekerasan, Lanjut Usia korban tindak kekerasan; pekerja migran korban tindak kekerasan, eksploitasi dan diskriminatif.

(8) Kerentanan sosial, meliputi individu, keluarga dan warga masyarakat yang berpotensi menjadi penyandang masalah kesejahteraan sosial.

(9) Keterbatasan daya dukung lingkungan, yaitu terbatasnya lahan atau ruang publik yang diperuntukkan bagi sarana sosialisasi masyarakat kota, maupun untuk kepentingan sosial lainnya seperti tanah pemakaman, ruang bermain dan sebagainya.

b. Disamping permasalahan sosial, di kota Jakarta terdapat berbagai potensi dan sumber kesejahteraan sosial, untuk meningkatkan pelayanan sosial, yaitu:

(1) Nilai kesetiakawanan dan rasa kepedulian sosial, yang masih dipunyai masyarakat kota Jakarta terhadap lingkungannya.

(2) Organisasi sosial, lembaga swadaya masyarakat, organisasi keagamaan, kelompok-kelompok masyarakat peduli, dan sebagainya

(3) Tanggungjawab sosial dunia usaha (Corporate Social Responsibility)

(4) Pendayagunaan modal sosial (jaringan sosial, kearifan budaya, pranata sosial). 


\section{Strategi Pengembangan Pelayanan Sosial}

Sesuai dengan uraian dalam analisis dan konsep dasar diatas serta berdasarkan rumusan analisis SWOT yang telah dilakukan, maka selanjutnya dapat dibuat formulasi untuk mendapatkan strategi pengembangan pelayanan sosial dalam bentuk tabel berikut :

Berdasarkan tabel di atas maka dapat ditetapkan strategi pengembangan pelayanan sosial diperkotaan. Strategi-strategi tersebut dapat disimpulkan secara garis besar sebagai berikut:

\section{Strategi Kemitraan}

Strategi Kemitraan, mengandung arti kerjasama dalam kesetaraan dan kebersamaan, dengan kepedualian, kesamaan keinginan dalam pengembangan pelayanan sosial di perkotaan, sehingga potensi dan sumber kesejahteraan sosial yang tersedia dapat digunakan untuk kegiatan-kegiatan yang dimaksud.

Strategi Kemitraan tersebut dapat dijabarkan menjadi :

- Meningkatkan kemitraan antara Pemerintah Pusat dengan

- Pemerintah Daerah; Pemerintah Daerah dengan Pemerintah Daerah; Pemerintah Daerah dengan Swasta atau Masyarakat.

- Meningkatkan kerjasama antar daerah dalam mengatasi masalah migrasi dan kaum marjinal (PMKS) perkotaan berupa pengembalian PMKS ke daerah asal; pengembangan fasilitas pelayanan sosial di

\section{Tabel 2}

Formulasi Strategi SWOT

Pelayanan Sosial Perkotaan

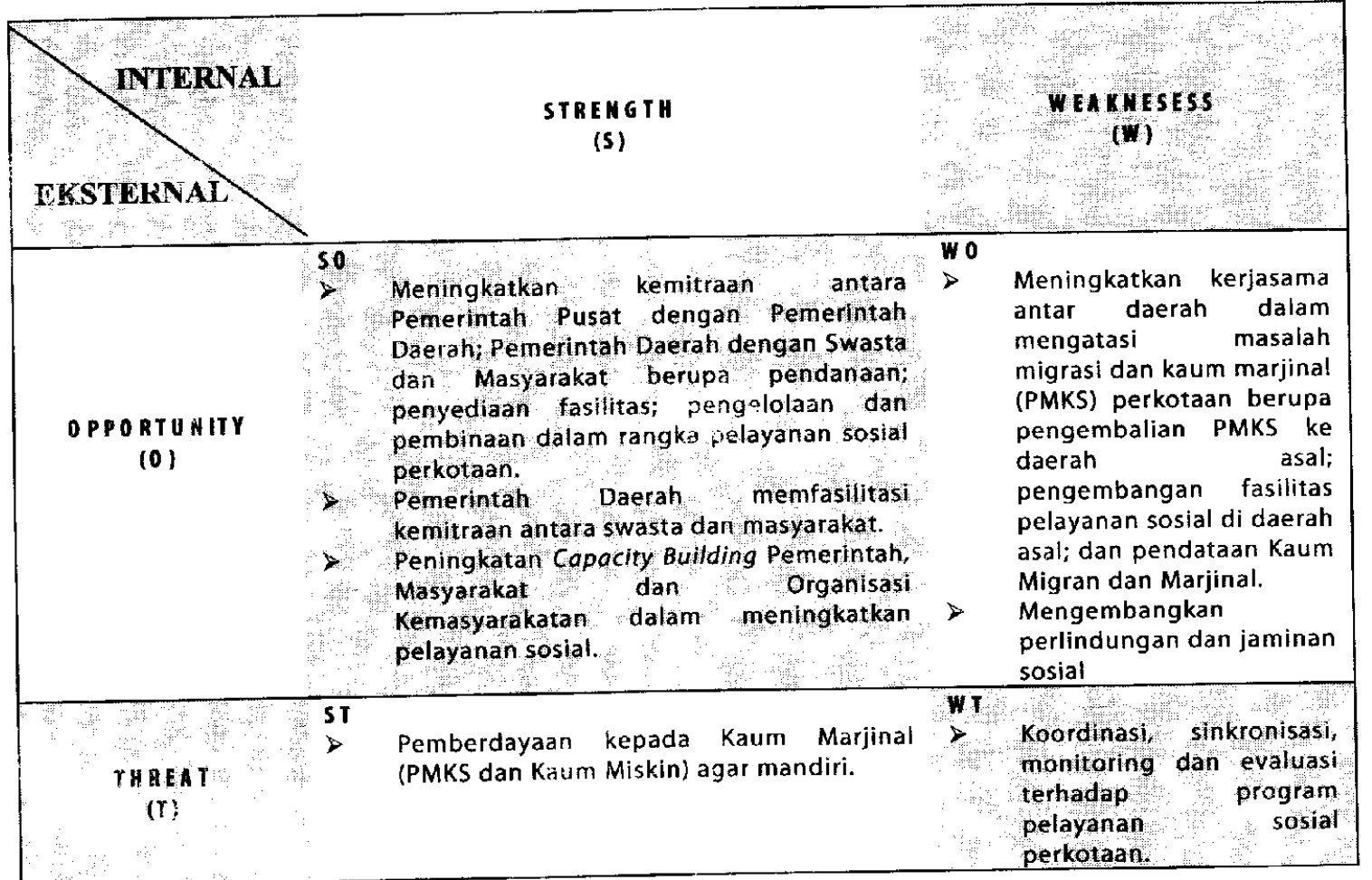


daerah asal; dan pendataan Kaum Migran dan Marjinal.

- Pemerintah Daerah memfasilitasi kerjasama antara swasta dan masyarakat.

\section{Strategi Pemberdayaan}

Strategi Pemberdayaan, mengandung makna prakarsa dan peran serta seluruh stakeholder dalam peningkatan kemampuan diri maupun sasaran pelayanan secara mandiri ataupun dengan dukungan pihak lain dalam pengembangan pelayanan sosial perkotaan.

- Pengembangan perlindungan dan jaminan sosial

- Pemberdayaan kepada Kaum Marjinal (PMKS dan Kaum Miskin) agar mandiri

\section{Strategi Penguatan Kelembagaan dan Sumber Daya Manusia}

Strategi penguatan kelembagaan dan Sumber Daya Manusia (SDM), mengandung pengertian peningkatan profesionalisme dan kinerja pelaku sekaligus peningkatan kualitas pelayanan sosial perkotaan.

Peningkatan Capacity Building Pemerintah, Masyarakat dan Organisasi Kemasyarakatan dalam meningkatkan pelayanan sosial.

- Koordiriasi, sinkronisasi, monitoring dan evaluasi terhadap program pelayanan sosial perkotaan.

\section{Program dan Rencana Aksi Pelayan- an Sosial Perkotaan}

Adapun program-program dan ren. ana aksi pengembangan pelayanan si al perkotaan yang dapat dikemukakan disini adaiah:
1. Program Kemitraan antara Pemerintah Pusat dengan Pemerintah Daerah (Pemda); Pemda dengan Pemda; Pemda dengan pihak Swasta atau Pemda dengan Masyarakat (Penyediaan fasilitas pelayanan sosial, Pengelolaan dan Pengembangan Program, Pemberian bantuan kerjasama usaha kecil, Pengembangan jaringan kerjasama antar unit kerja, dibidang penggalangan dana, informasi dan data, maupun pengembangan program di bidang pelayanan kesejahteraan sosial).

2. Program Kemitraan, dimana Pemerintah Daerah memfasilitasi kerjasama antara swasta dengan masyarakat (Pembuatan regulasi/ kebijakan tentang porsi, kewenangan, batasan atau hal-hal yang berkaitan dengan pengembangan pelayanan sosial. Koordinasi penyaluran bantuan tanggap darurat).

3. Program Pemberdayaan (Pembinaan pengelolaan dan pendampingan, Subsidi dan bantuan teknis, Pendidikan dan pelatihan keterampilan usaha, Penyuluhan dan Advokasi sosial, Pengembangan usaha kecil produktif, Menumbuhkembangkan modal sosial masyarakat, Pengembangan sistem dan modal perlindungan serta jaminan sosial, Pembuatan regulasi/kebijakan yang diarahkan kepada peningkatan akses terhadap sumber-sumber kesejahteraan sosial dan ekonomi).

4. Program penguatan kelembagaan dan Sumber Daya Manusia (SDM) (Pengkajian kebijakan dan penyusunan rencana pelayanan sosial, Pengembangan model pelayanan sosial, Pembentukan dan pengembangan sistem informasi, basis data serta jaringan kerja). 


\section{Simpulan}

Kontribusi jumlah PMKS terbesar terhadap jumlah penduduk terjadi di Kota Jakarta Pusat sebesar 1,7 persen. Selanjutnya diikuti oleh Kota Jakarta Timur (1,1 persen); Kota Jakarta Utara $(0,9$ persen); Kota Jakarta Barat $(0,4$ persen) dan yang terendah berada di Kota Jakarta Selatan sebesar 0,3 persen. Jenis PMKS dengan populasi terbanyak adalah Anak Terlantar.

Jenis Potensi dan Sumber Kesejahteraan Sosial (PSKS) mengalami peningkatan, sedangkan untuk jenis PSKS lainnya seperti Pengurus Karang Taruna, Pengurus Pokja Kesuma dan Pengurus Orsos/Badan Sosial nampaknya tidak mengalami peningkatan. Meskipun demikian dapat dikatakan bahwa telah terjadi peningkatan peranserta sosial masyarakat baik itu secara jumlah dan kualitas Tenaga Kerja Sosial Masyarakat (TKSM) dan Orsos/ LSM yang berperan aktif dalam memberikan pelayanan social di Provinsi DKI Jakarta.

Strategi yang dirumuskan yaitu strategi kemitraan, strategi pemherdayaan dan strategi penguatan "tembagaan, sedangkan rencana $a k \cdot$ pengembangannya dirumuskan kedalam program kemitraan antara pemerintah pusat dan daerah, pemda dengan swasta, pemda dengan masyarakat; progam kemitraan tersebut: juga dapat dilaksanakan melaiui mekanisme fasilitasi pemda terhadap masyarakat dan swasta; program pemberdayaan dan program penguatan kelembagaan dan sumberdaya manusia dengan rencana aksi meliputi peng- kajian kebijakan dan penyusunan rencana pelayanan sosial, Pengembangan model pelayanan sosial, pembentukan dan pengembangan sistem informasi, basis data serta jaringan kerja.

\section{Daftar Pustaka}

Burchell, Robert W. And George Sternilieb.1979. Planning theory in the 1980's: A Search for Future Directions. New Brunswick, NJ: Rutgers University Press.

Campbell, Scott and Susan Fainstein, eds. 1996. Reading in Planning Theory. Cambridge, Massachusetts: Blackwell Publishers.

C.N Ray, Rawat. 2003. Utitan Social Sevices, New Dehi, India,

Day, Kristen. 2003 . New Urbanism and The Chailanges of Desigging for Diversity. Journal of Education Planning Education and Research. Vol. 23.

DKI Jakarta Dalam Angka. 2005, Bappedda Propinsi Daerah Khusus Ibukota Jakarta, lakarta.

DKI Jakarta Dalam Angka. 2006, Bappeda Propinsi Darah Khusus lbukota Jakartt, lakarita.

Fainstein, Susan S. 2001. Competitiveness, Cohession, and Governance: Their Implication for Social Lustice. International Juurnal of urban and Regional Research. Vol 25 (4).

Fishman, Robert. 199. Urban Utopias: Ebenezer Howard and Le Corbusier. Chapter 2 in Campbell, Scott and Susan Fainstein, eds. Rezding in Planning Theory. Cambridge, Massachusetts: Blackwell Publisher.

Galloway. Thomas Q. And Riad G, Mahayni. Planning Theory in Retrospect: The Process of Paradigm Change. The Journal of the American Planning Association. January 1997, 62-71.

Hall, Peter. 1988. Cities of Tommorow. Cambridge, Massachussetts: Blackwell Pubisher.

Rencana Pembanguran Jangka Mienengah OKK J akarta 2005-2010, Bappeda Propinsi Dareah Kh Wusus b bukota Jakarta, Jakarta.

Whyte, William H. 1980. The Social Life of Small Urtan Spaces. Washington D.C:The Conservation Foundation

Susan A. Reidinger, etc. 1999. Income Support and Social Services", New York. 